\title{
Performance of broiler birds fed graded levels of clove (Syzgium aromaticum (L.) buds powder in semi-arid region, Nigeria
}

\author{
Usman, H. B ${ }^{1}$ and Aljameel, K. M ${ }^{2 \star}$ \\ 1Department of Animal Science, Federal University Dutsin-ma, Katsina, Nigeria. \\ 2Department of Animal Science, Usmanu Danfodiyo University, Sokoto, Nigeria. \\ *Corresponding author: muhdkjameel@gmail.com; Tel: +2348035299059.
}

Copyright (C) 2021 Usman and Aljameel. This article remains permanently open access under the terms of the Creative Commons Attribution License $\underline{4.0}$, which permits unrestricted use, distribution, and reproduction in any medium, provided the original work is properly cited.

Received 4th September, 2021; Accepted 28th September, 2021

\begin{abstract}
The study was conducted on broiler chickens to investigate the effect of graded levels of clove buds powder fed on performance. A total of 288 broiler chickens were being used. The broiler chickens randomly divided into four treatments groups (four experimental diets): $T_{1}$ (control), $T_{2}(0.5 \mathrm{~kg} / 100 \mathrm{~kg}), T_{3}(1 \mathrm{~kg} / 100 \mathrm{~kg})$ and $T_{4}(1.5 \mathrm{~kg} / 100 \mathrm{~kg})$. At the starter phase of experiment, the broiler chickens in treatment $4(1.5 \mathrm{~kg} / 100 \mathrm{~kg}$ cloves $)$ show better performs $(p<0.05)$ in final body weight, body weight gain and body weight gain per bird compared to birds in treatment 1 (control) and treatment $2(0.5 \mathrm{~kg} / 100 \mathrm{~kg})$. The final phase of the study shows significantly $(\mathrm{p}<0.05)$ decreases in feed intake, average daily feed intake and mortality rate with increasing levels of the clove buds powder fed, while body weight and weight gain were increase significantly $(p<0.05)$ with increasing levels of the clove buds powder fed. The study concludes that the use of ingredients of the cloves in poultry diet significantly $(p<0.05)$ improves performance at $1.5 \mathrm{~kg} / 100 \mathrm{~kg}$ fed inclusion for broiler birds at starter and final phase.
\end{abstract}

Keywords: Broilers, cloves bud, performance, poultry.

\section{INTRODUCTION}

Broilers of modern intensive production are challenged by various disorders, infections, heat stress, and stress caused by management, resulting in economic losses (Zhang et al., 2009). Poultry feed is one of the highest expenses for poultry producers, and can constitute 60 to $70 \%$ of the total cost of broiler production (Sugiharto and Ranjitkar, 2019). Alternatives to feedstuffs which are economically cheaper are being examined by nutritionists, traditional feedstuffs used in poultry diets, with the goal of reducing costs without compromising bird performance. Agro-industrial by-products are one such unconventional feed ingredient that could help decrease feed costs while increasing profits (Sugiharto et al., 2018); however, most of these products are high in fiber, low in protein, and contain other anti-nutritional factors that negatively affect digestibility. Antibiotics are used to enhance productivity by improving intake though the use of antibiotics as feed additives had been a hallmark of modern animal husbandry; however, this widespread practice is not without criticism (Butaye, 2003). Concerns were raised that the use of antibiotics as therapeutics and for growth promotion could lead to a problem of increasing resistance in bacteria of human and animal origin, particularly regarding resistance in gram- negative bacteria (Salmonella spp. and Escherichia coli).

In Nigerian poultry farms, it is a common practice to add antibiotics in drinking water at the time of vaccinations. Antibiotics are also added in self formulated and commercial feeds. Antibiotics are also given as medications in prevention and control instances. Most farmers administer antibiotics at the time of vaccination without scientific knowledge of the effects on the immune response (Abubakar et al., 2021). The feed industry is facing the challenge of the awareness among the consumers of meat on the risk of bringing about antibiotic resistance in pathogenic microbiota through antibiotics 
used in animal and poultry feeds. It has directed them towards the non-antibiotic feed additives. Among them, the feed additives of plant origin, called as Phytogenic Feed Additives (PFA) or Phytobiotics or Phyto-additives are considered to be a better alternative as non-antibiotic growth promoters, even though there are well established non antibiotic growth promoters such as organic acids and probiotics (Abubakar et al., 2021). The phytogenic feed additives also vary widely in their botanical origin, processing and composition. They have been used in solid, dried and ground forms or as extracts or essential oils (Guo et al., 2003). Therefore, there is a need to exploit different natural plant products to achieve better production of farm animals (Cruz et al., 2014; Valero et al., 2014; Valero et al., 2015).

Herbs and spices (such as cinnamon, oregano, thyme, ginger, garlic, cloves etc) are known to have health benefits such as appetite and digestion stimulants (Janz et al., 2007), anti-microbial action (Di Pasqua et al., 2006; Windisch et al., 2008), anti-inflammatory action (Craig, 1999; Srinivasan et al., 2005), anti-oxidative action (Craig, 1999; Fasseas et al., 2008) and immune-stimulant function (Craig, 1999) on animals when used as feed additives in animal nutrition. For effective use of herbs and spices, they can be added to feed as dried plants or as extracts. Therefore, the objective of this study was to investigate the effect of graded levels of clove buds powder on performance of broiler chickens.

\section{MATERIALS AND METHODS}

\section{The study area}

The study was carried out at the poultry production unit of the Teaching and Research farm in the Department of Animal Science, Faculty of Agriculture, Usmanu Danfodiyo University, Sokoto. Sokoto is located between latitudes $12^{\circ}$ and $13^{\circ} \mathrm{N}$ and Longitudes $4^{\circ}$ and $6^{\circ} \mathrm{E}$ in the northern part of Nigeria and lies at an altitude of $350 \mathrm{~m}$ above the sea level (Mamman et al., 2000).

\section{Experimental design}

\section{The experimental birds}

A total of 288 apparently healthy broiler chickens were used in this study. The chickens divided randomly into 4 treatments groups (72 birds per treatment), each group divided into sub-group consist of 12 birds and replicated for 6 times.

\section{The experimental diets}

The cloves buds powder was used as additives in this experiment. The cloves buds powder additives used were in four (4) graded levels of $0,0.5,1$ and $1.5 \mathrm{~kg} / 100 \mathrm{~kg}$.

\section{Experimental birds and their management}

The boiler chicks for this study were obtained from reputable farm in Nigeria at age of one day. The birds were transported to Sokoto under the cool hours of the evening through the night and arrived in the morning hours. The poultry house was cleaned, washed and disinfected before a week prior to arrival of the birds. The birds were raised on deep litter in tropical house type, with open side walls and concrete floor. Litter materials (wood shavings and old newspaper were spread on the floor, feeding trays and small drinkers were used for the first 0 to 2 weeks (starter phase), while conical feeders and plastic containers with wire guard were used at final phase. Feed was given to the birds ad libitum on tray feeders for the first 10 days and the tray feeders were replaced with small conical feeders at second week of their age for proper feed management and efficiency. Fresh water was given to the birds every morning in small drinkers. Their health care was ensured by giving them routine vaccination and medication as at when due, proper sanitation and hygiene was ensured. The floor spacing was maintained at $(4 / 9 \mathrm{ft})$ per replicate (Oluyemi and Roberts, 2000).

\section{Experimental diet formulation}

Maize, wheat offal, bone meal, fish meal and salt were obtained from Sokoto central market. Soya bean meal, groundnut cake, limestone and micro ingredients such as premix, lysine, and methionine were sourced from a vendor called Alkanchi Farm Ltd in the Sokoto metropolis. The cloves was also purchased Sokoto central market and ground into powder form.

Feed ingredients that were used for this experiment, such as maize, groundnut cake (GNC), soya bean meal and bone meal required crushing so that the particle size will suit the group of birds the feed are to be meant for. Feed ingredients that were in powdery form were weighed and mixed with the crushed ones. The feed compounding was done on a clean concrete floor, and thoroughly mixed with shovel to a uniform mix. The feed compounding was done according to the formulation in Table 1.

\section{Data collection}

Daily feed intake $=$ Feed given $(\mathrm{g}$ or $\mathrm{kg})-$ Feed leftover $(\mathrm{g}$ or $\mathrm{kg}$ ).

Body Weight $(B W)=$ Current/Final weight - Initial/previous weight.

Body Weight Gain (BWG) = Current/Final weight Initial/previous weight.

Feed Conversion Ratio $=\frac{\text { Feed Intake }}{\text { Weight Gain }}$

Mortality was recorded as it occurred on daily basis. 
Table 1. Gross, calculated and analyzed chemical composition of experimental starter and finisher diets.

\begin{tabular}{|c|c|c|}
\hline Ingredient (kg) & Starter & Finisher \\
\hline Maize & 50.0 & 55.5 \\
\hline Soya beans meal & 19.0 & 13.0 \\
\hline Groundnut cake & 15.5 & 12.0 \\
\hline Fish meal & 2.5 & 1.50 \\
\hline Wheat offal & 8.0 & 11.0 \\
\hline Limestone & 2.0 & 4.0 \\
\hline Bone meal & 2.0 & 4.0 \\
\hline Premix & 0.25 & 0.25 \\
\hline Salt & 0.25 & 0.25 \\
\hline Methionine & 0.25 & 0.25 \\
\hline Lysine & 0.25 & 0.25 \\
\hline Total & $100 \mathrm{~kg}$ & $100 \mathrm{~kg}$ \\
\hline \multicolumn{3}{|c|}{ Calculated Chemical Composition } \\
\hline Crude protein (\%) & 23 & 19.05 \\
\hline Energy $(\mathrm{kcal} / \mathrm{kg})$ & 2986 & 3352 \\
\hline Methionine & 0.36 & 0.41 \\
\hline Lysine & 1.0 & 0.9 \\
\hline Calcium & 0.8 & 0.8 \\
\hline Phosphorus (av) & 0.45 & 0.45 \\
\hline Fibre (\%) (max) & $6 \%$ & 6 \\
\hline \multicolumn{3}{|c|}{ Analysed value of feed } \\
\hline Crude protein (\%) & 22 & 20 \\
\hline Energy $(\mathrm{kcal} / \mathrm{kg})$ & 3001 & 3450 \\
\hline Methionine (\%) & 0.5 & 0.5 \\
\hline Lysine (\%) & 1.0 & 0.9 \\
\hline Calcium (\%) & 1.4 & 2.6 \\
\hline Phosphorous (\%) & 0.6 & 0.8 \\
\hline Fibre (\%) & 5.4 & 5.1 \\
\hline
\end{tabular}

\section{Data analysis}

Analysis of variance (ANOVA) of SPSS software 2017 version was used to compare the means of parameters of study. The results were expressed in the form of means \pm standard error. The difference between the means of the parameters under study were consider statically significant when the $p$ value less than $0.05(p<0.05)$.

\section{RESULTS AND DISCUSSION}

\section{Performance of broiler birds fed graded levels of cloves powder at starter phase (0-4 weeks)}

The performance of broiler birds fed graded levels of cloves powder at starter phase is presented in Table 2. The results show significantly difference $(p<0.05)$ in all the parameters (total feed intake, average daily feed intake, final body weight, body weight gain, body weight gain per day, feed conversion ratio) except initial body weight.
Broiler birds fed treatment $4(1.5 / 100 \mathrm{~kg})$ shows better performs $(p<0.05)$ in final body weight, body weight gain and body weight gain per bird compared to birds in treatment 1 (control) and treatment $2(0.5 / 100 \mathrm{~kg})$. This indicates better utilisation of feed. The values obtained in this study were much lower than $1215 \mathrm{~g}$ obtained for broilers at week 4 by Dafwang (2006) and the range of 1005.06 to $1143.09 \mathrm{~g}$ reported by Afolayan et al. (2014).

Feed intake was lower $(p<0.05)$ in treatment 3 and 4 , which might be as a result of high level of cloves which contain high levels of phenolic compounds (Diego et al., 2014). Compared to the other treatments (1 and 2), there is no significant $(p>0.05)$ difference between the control and treatment 2 in all the parameters measured except in total and average daily feed intake. This may be as a result of lower inclusion level of cloves bud powder of 0.5 $\mathrm{kg} / 100 \mathrm{~kg}$ in treatment 2 . Birds in treatment 3 and 4 records better feed conversion ratio compared to treatment 1 and $2(p<0.05)$. According to Etuk and Udedibie (2003), Akinmutimi (2003), Amaefule and Onwudike (2003), Ani and Okeke (2003) and Esonu et al. (2003), the most 
Table 2. Performance of broiler birds fed graded levels of cloves powder at Starter Phase (0-4 weeks).

\begin{tabular}{|c|c|c|c|c|c|}
\hline \multirow{2}{*}{ Parameters } & \multicolumn{4}{|c|}{ Treatments } & \multirow{2}{*}{ SEM } \\
\hline & $\mathrm{T}_{1}$ (control) & $T_{2}(0.5 \mathrm{~kg} / 100 \mathrm{Kg})$ & $T_{3}(1 \mathrm{~kg} / 100 \mathrm{~kg})$ & $\mathrm{T}_{4}(1.5 \mathrm{~kg} / 100 \mathrm{~kg})$ & \\
\hline Total Feed Intake $(\mathrm{g})$ & $2793.50^{a}$ & $2772.11^{b}$ & $2589.36^{d}$ & $2611.03^{c}$ & 17.10 \\
\hline Average Feed Intake/Day (g) & $99.77^{\mathrm{a}}$ & $99.00^{\mathrm{b}}$ & $92.47^{d}$ & $93.28^{c}$ & 0.21 \\
\hline Initial body weight (g) & 37.45 & 37.55 & 37.46 & 37.84 & 0.56 \\
\hline Final Body Weight (g) & $522.20^{\mathrm{b}}$ & $510.93^{b}$ & $543.32^{a}$ & $570.22^{\mathrm{a}}$ & 10.29 \\
\hline Body Weight Gain (g) & $484.75^{b}$ & $473.38^{\mathrm{b}}$ & $505.86^{\mathrm{ab}}$ & $532.38^{\mathrm{a}}$ & 12.11 \\
\hline Body Weight Gain/Day & $17.31^{\mathrm{bc}}$ & $16.91^{c}$ & $18.06^{\mathrm{ab}}$ & $19.01^{\mathrm{a}}$ & 0.43 \\
\hline Feed Conversion Ratio & $5.76^{\mathrm{a}}$ & $5.86^{\mathrm{a}}$ & $5.12^{\mathrm{b}}$ & $4.91^{b}$ & 0.13 \\
\hline
\end{tabular}

$a, b, c$ Mean with different superscript across the row are significantly different $(p<0.05)$.

Table 3. Performance of Broiler Birds Performance of Broiler Birds fed graded levels of cloves powder at Finisher Phase (4-8 weeks).

\begin{tabular}{|c|c|c|c|c|c|}
\hline \multirow{2}{*}{ Parameters } & \multicolumn{4}{|c|}{ Treatments } & \multirow{2}{*}{ SEM } \\
\hline & $\mathrm{T}_{1}$ (control) & $\mathrm{T}_{2}(0.5 \mathrm{~kg} / 100 \mathrm{Kg})$ & $T_{3}(1 \mathrm{~kg} / 100 \mathrm{~kg})$ & $\mathrm{T}_{4}(1.5 \mathrm{~kg} / 100 \mathrm{~kg})$ & \\
\hline Total Feed Intake (g) & $5261.33^{a}$ & $5211.45^{\mathrm{ab}}$ & $5119.67^{b}$ & $5110.27^{b}$ & 38.67 \\
\hline Average Feed Intake/Day (g) & $187.89^{a}$ & $186.12^{a b}$ & $182.84^{b}$ & $182.51^{\mathrm{b}}$ & 1.37 \\
\hline Initial body weight (g) & $522.20^{\mathrm{b}}$ & $510.93^{b}$ & $543.32^{\mathrm{a}}$ & $570.22^{\mathrm{a}}$ & 10.29 \\
\hline Final Body Weight (g) & $1811.67^{c}$ & $1799.67^{c}$ & $1859.23^{b}$ & $1911.00^{a}$ & 14.24 \\
\hline Body Weight Gain (g) & $1289.47^{c}$ & $1288.74^{\mathrm{C}}$ & $1315.91^{\mathrm{b}}$ & $1340.78^{a}$ & 9.70 \\
\hline Body Weight Gain/Day & $46.05^{b}$ & $46.03^{b}$ & $47.00^{\mathrm{ab}}$ & $47.85^{\mathrm{a}}$ & 0.67 \\
\hline Feed Conversion Ratio & 4.08 & 4.04 & 3.89 & 3.81 & 0.11 \\
\hline Mortality (\%) & $5.04^{\mathrm{a}}$ & $1.44^{\mathrm{b}}$ & $0.72^{\mathrm{c}}$ & $0.00^{\mathrm{d}}$ & 0.04 \\
\hline
\end{tabular}

a,b,c Mean with different superscript across the row are significantly different $(p<0.05)$.

important factor influencing the performance of poultry birds is the quality of the feed offered to the birds. This support the finding of this study where feed performance was improved as a result of inclusion of cloves bud powder.

\section{Performance of broiler birds fed graded levels of} cloves buds powder at finisher phase (4-8 weeks)

The result of finisher phase is presented in Table 3. The result shows significant difference $(p<0.05)$ in all the parameters measured except feed conversion ratio. Broiler birds fed $1.5 \mathrm{~kg} / 100 \mathrm{~kg}$ cloves bud powder records low feed intake, average daily feed intake and mortality compare to the other treatments $(1,2$ and 3$)$. The result shows that feed intake, average daily feed intake and mortality decreases significantly $(p<0.05)$ with increasing levels of clove buds powder while body weight and weight gain increase significantly $(p<0.05)$ with increasing levels of the test ingredients). Cloves have high content of antioxidant and phenolic compounds such as eugenol acetate which are reported to improve performance parameters (Diego et al., 2014).

\section{Conclusion}

The study concludes that ingredients of cloves in poultry diet significantly $(p<0.05)$ improved performance of broiler birds at starter and finisher phase at rate of $1.5 \mathrm{~kg} / 100 \mathrm{~kg}$ inclusion of fed.

\section{CONFLICTING INTERESTS}

The authors declare that they have no conflict of interest.

\section{REFERENCE}

Abubakar, S., Abdullahi, A. U., Usman, M. L., Sani, G., \& Usman, H. B. (2021). Performance of broilers birds administered graded levels oxytetracycline in sokoto, Nigeria Asian Journal of Animal Science 11(3), 20-24.

Afolayan, S. B., Dafwang, I. I., Tegbe, T. S. B., Sekoni, A., \& Jegede, J. O. (2014). Performance of broiler chickens fed maize based diets substituted with graded levels of sweet potato meal. Nigeria Journal of Animal Production, 41(1), 5059.

Akinmutimi, A. H. (2003). Effect of processing on metaboliszability of energy content of sword beans (Canavalia gladiata) using broiler chicks (starter phase). Proceedings of the 28th Annual Conference of the Nigeria Society for Animal Production (NSAP), Ibadan, Nigeria. Pp. 194-196.

Amaefule, K. U and Onwudike, O. C., (2003). Comparative evaluation of the processing methods for pigeon pea seeds (Cajanus cajan) as protein source for broilers. East African Agricultural and Forestry Journal, 68(3-4),191-196 
Ani, A. O and Okeke, G. C., (2003). The substitution of pigeon pea (Cajanus cajan) seed meal for soybean meal in broiler finisher rations. Proceedings of 8th Annual Conference of Animal Science Association of Nigeria (ASAN), Federal University of Technology, Minna, Nigeria, Pp.10-12.

Butaye, P., Devriese, L. A., \& Haesebrouck, F. (2003). Antimicrobial growth promoters used in animal feed: Effects of less well known antibiotics on gram-positive bacteria. Clinical Microbiology Reviews, 16(2), 175-188.

Craig, W. J. (1999). Health-promoting properties of common herbs. American Journal of Clinical Nutrition, 70(3 Suppl), 491S-499S.

Cruz, O. T. B., Valero, M. V., Zawadzki, F., Rivaroli, D. C., do Prado, R. M., Lima, B. S., \& do Prado, I. N. (2014). Effect of glycerine and essential oils (Anacardium occidentale and Ricinus communis) on animal performance, feed efficiency and carcass characteristics of crossbred bulls finished in a feedlot system. Italian Journal of Animal Science, 13, 790-797.

Dafwang, I. I. (2006). Meat, eggs and milk from farm waste: Explorations in animal nutrition research and extension-an inaugural lecture. University Organized Lectures Committee, Vice Chancellor's Office, Ahmadu Bello University, Zaria, Nigeria, 63.

Di Pasqua, R., Hoskins, N., Betts, G., \& Mauriello, G. (2006). Changes in membrane fatty acids composition of microbial cells induced by addiction of thymol, carvacrol, limonene, cinnamaldehyde, and eugenol in the growing media. Journal of Agricultural and Food Chemistry, 54(7), 2745-2749.

Diego, F. C., Claudia, R. F., \& Wanderley, P. O. (2014) Cloves (Syzgium aromaticum): a precious spice. Asian Journal of Tropical Biomedicine, 4(2), 90-96

Esonu, B. O., Ihenkwumere, F. C., Iwuji, T. C., Akamu, N and Nwugo, O. H., (2003). Evaluation of Microdermis puberula leaf meal as an ingredient in broiler starter diets. Nigerian Journal of Animal Production, 30(1), 3-8.

Etuk, E. B., \& Udedibie, A. B. I. (2003). Effect of cooked pigeon pea (Cajanus cajan) seed meal on the performance of broiler chicks. Journal of Agriculture and Social Research, 3(1), 1-12.

Fasseas, M. K., Mountzouris, K. C., Tarantilis, P. A., Polissiou, M., \& Zervas, G. (2008). Antioxidant activity in meat treated with oregano and sage essential oils. Food Chemistry, 106(3), 1188-1194.

Guo, F. C., Savelkoul, H. F. J., Kwakkel, R. P., Williams, B. A., \& Verstegen, M. W. A. (2003). Immunoactive, medicinal properties of mushroom and herb polysaccharides and their potential use in chicken diets. World's Poultry Science Journal, 59(4), 427-440.
Janz, J. A. M., Morel, P. C. H., Wilkinson, B. H. P., \& Purchas, R. W. (2007). Preliminary investigation of the effects of low-level dietary inclusion of fragrant essential oils and oleoresins on pig performance and pork quality. Meat Science, 75(2), 350-355.

Mamman, A. B., Oyebanji, J. O., \& Peter S. W. (2000). A people United, a future assured survey of state. Vol. 1(112). Gabumo publishing co. Ltd. Calabar, Nigeria.

Oluyemi, J. A and Roberts, S. A. (2000). Poultry production in warm wet climates. 2nd edition Spectrum Book Ltd, Ibadan, Nigeria. p. 244.

Srinivasan, K., Muruganandan, K. N., \& Chandra, S. (2001). Antiinflammatory and analgesic activity of some medicinal plants. Journal of Medicinal and Aromatic Plant Sciences, 22, 56-58.

Sugiharto, S., \& Ranjitkar, S. (2019). Recent advances in fermented feeds towards improved broiler chicken performance, gastrointestinal tract microecology and immune responses: A review. Animal Nutrition, 5(1), 1-10.

Sugiharto, S., Yudiarti, T., Isroli, I., \& Widiastuti, E. (2018). The potential of tropical agro-industrial by-products as a functional feed for poultry. Iranian Journal of Applied Animal Science, 8(3), 375-385.

Valero, M. V., Torrecilhas, J. A., Zawadzki, F., Bonafe, E. G., Madrona, G. S., Prado, R. M. D., ... \& Prado, I. N. D. (2014). Propolis or cashew and castor oils effects on composition of Longissimus muscle of crossbred bulls finished in feedlot. Chilean Journal of Agricultural Research, 74(4), 445451.

Valero, M. V., Zawadzki, F., Prado, R. M., Fugita, C. A., Rivaroli, D. C., Ornaghi, M., \& Prado, I. N. (2015). Propolis and functional oils (cashew and castor oils) on animal performance, apparent digestibility and blood cells of growing crossbred bulls reared in an intensive system. Revista Colombiana de Ciencias Pecuarias (in press).

Windisch, W., Schedle, K., Plitzner, C., \& Kroismayr, A. (2008). Use of phytogenic products as feed additives for swine and poultry. Journal of animal science, 86(suppl_14), E140-E148.

Zhang, G. F., Yang, Z. B., Wang, Y., Yang, W. R., Jiang, S. Z., \& Gai, G. S. (2009). Effects of ginger root (Zingiber officinale) processed to different particle sizes on growth performance, antioxidant status, and serum metabolites of broiler chickens. Poultry science, 88(10), 2159-2166. 